\title{
Porosity-Permeability Relationships in the Early Oligocene Algal Limestone Member of Wadi Al Buwayrat, Tansolukh Area, Al Jabal Al Akhdar, NE Libya
}

\author{
Omar B. Elfigih, Ebrahim A. Al-Orabi \\ Department of Earth Sciences, Faculty of Science \\ University of Benghazi, Benghazi-Libya
}

\begin{abstract}
This paper reports a series of ten (10) porosity - permeability analyses and supporting petro graphic and sedimentologic descriptions from the Early Oligocene (Al Bayda Formation) of Algal Limestone Member strata sampled from an escarpment in Wadi Al Buwyrat, Tansolukh Village, Al Jabal Al Akhdar.

The samples analyzed are not only mainly coarse bioclastic limestone from platform -top facies, but also include some micritic or lime-mud rock plugs from deeper water slope to basinal facies. Outstanding characteristics of this data set are the wide ranges of porosity (total; $\emptyset_{t}$ and macro; $\emptyset_{m}$ ) and permeability $(K)$ in all studied limestone samples and the large degree of short - range heterogeneity typical of these strata, and the better total porosity -macro-porosity correlation of the studied Algal Limestone. The Algal limestone samples as revealed by petrographic examination, have experienced widely varying calcite cementation, some clay-rich (micritic) limestone and dissolution through some vuggy porosity and localized moldic porosity which may show clear evidence of meteoric diagenesis, suggesting that sub-aerial exposure may have played an important role in porosity-permeability evolution.

Permeability for -given - porosity is controlled by grain size calcite cement and provided vuggy porosity, and by the occurrence of some unconnected moldic porosity in mud-rich samples. As a result, there is no correlation in porosity- between total $\left(\emptyset_{t}\right)$ and macro porosity $\left(\emptyset_{m}\right)$ and their equivalent permeabilites $(K)$. This trendless relationship may be interpreted as reflecting an overall lower permeability for a given porosity that led to more muddy depositional facies greater cementation and lesser grain dissolution and connectivity.
\end{abstract}

Keywords: Graphic representation; Total porosity; Macro porosity; Permeability; Algal Limestone; Tansolukh area.

\section{INTRODUCTION}

The area of investigation is a part of Wadi Al Buwayrat, Tansolukh region, represented by stepped high escarpment composed mainly of a thick bedded Alga Limestone Figure 1.

This paper summarizes porosity - permeability data from ten elevation points (155m to $177 \mathrm{~m})$ where good exposure of Algal Limestone rocks is characterizing one of the highest escarpment at Wadi Al Buwayrat Figure 1. Also it describes the sample materials and their lithologic and stratigraphic context, discusses probable controlling factors on porosity- permeability data, and how total porosity (rock plug porosity; $\emptyset_{\mathrm{t}}$ ) and macroporosity (thin section porosity; $\emptyset_{\mathrm{m}}$ ) may affect permeability $(\mathrm{K})$ of the investigated rock unit. Together with observation about sedimentology, stratigraphy and petrography, these data provide a comprehensive characterization of the petrophysical parameters (porosity "Ø" and permeability " K") of the Algal Limestone units in the study area .

Published information on the permeability-porosity relationship and trends of micro porosity/total plug porosity versus permeability is sparse, but general reviews are given in Saller and Henderson (1998) [1], Ehrenberg (2004a) [2], Ehrenberg et al. (2004b) [3], Ehrenberg et al. (2006) [4], Baker et al. (2013) [5], AlRatrout et al. (2014) [6] and Rahmouni et al. (2014) [7]. 


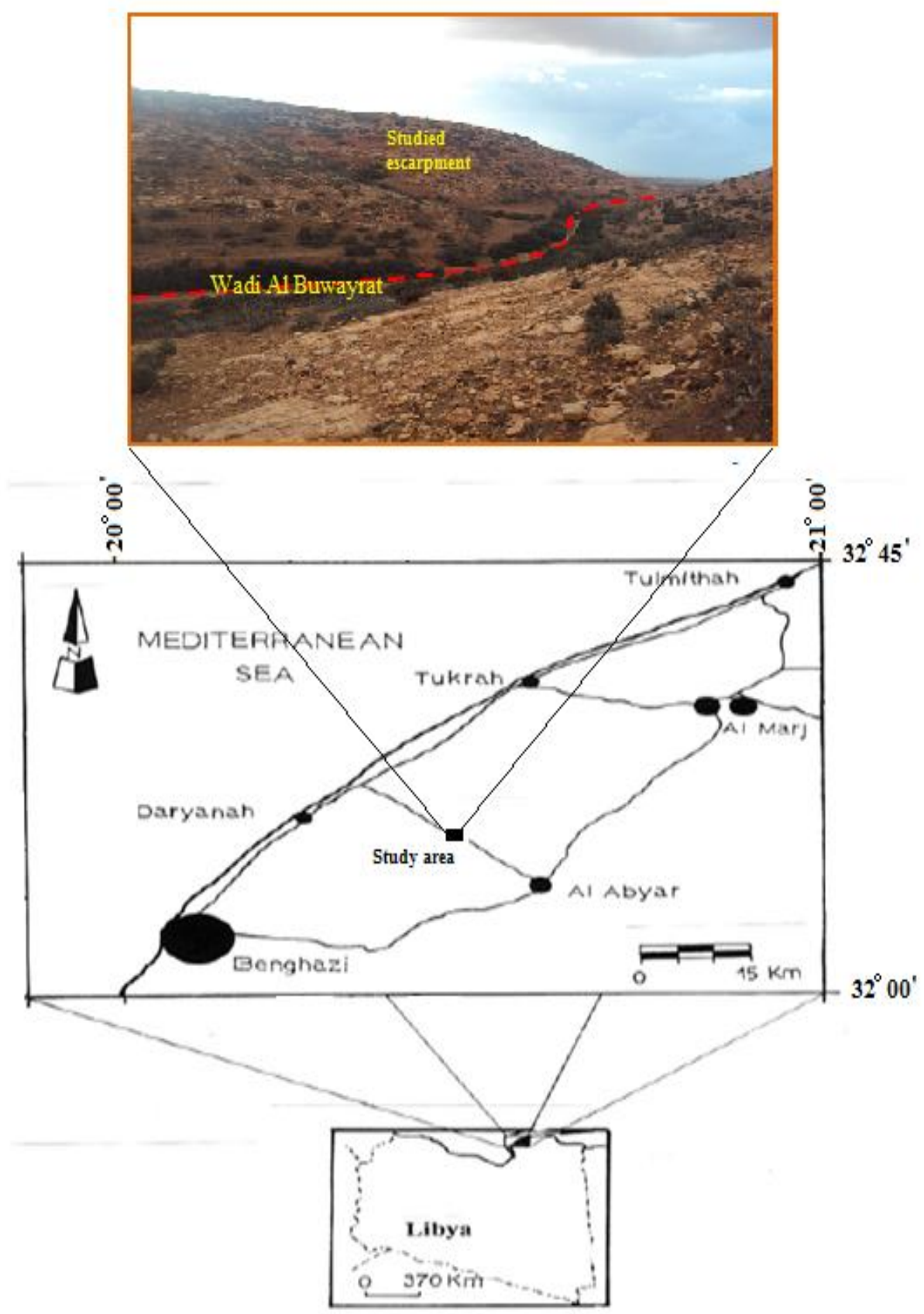

Figure1. Location map of studied escarpment showing studied traverse (dashed arrow), Wadi Al Buwayrat, Tansolukh area, Al Jabal Al Akhdar, Libya.

\section{Geological SetTing}

Structurally, the studied area represents a part of Al Jabal al Akhdar anticlinorium Figure 2 [8]. Beds are dipping few degrees to the southwest. Al Jabal al Akhdar is located south of the Mideterranian geosyncline and north of the Sahara platform. It is also defined as an uplifted trough of the northern part of Cyrenica platform forming a complex arch elongated in the ENE-WSW directions $[9,10]$. Stratigraphically, the region is a result of the development of sedimentary cycles consisting of marine carbonate units of different thicknesses and bedding fashion and ranging in age from Late Cretaceous to Late Miocene Figure $3[11,12]$. Oligocene was a time of regression, tectonic activity and volcanism throughout northeast Africa [13].

The Eocene -Oligocene boundary suggests that diastrophic movement took place at the end of Eocene [12].The Early Oligocene marine transgression was covered a small part of Al Jabal al Akhdar, allowing for the deposition of Shahat Marl and grades upward to the overlain Algal Limestone (Al Bayda Formation). The Early Oligocene sedimentation was followed by a tecto-eustatic regression that led to the development of an unconformity surface at the top of Algal Limestone [12]. According to Rohlich [14] and due to the diverse distribution of Al Bayda Formation Figure 4, the paleogeography of the area as a whole was changed again during the Middle to Late Oligocene times. 
In the study area, the studied escarpment at Wadi Al Buwayrat is mainly composed of a series of thickly bedded Algal Limestone rock, these rock units are widely observed in the vicinity of Wadi Al Buwayrat. A studied traverse between elevation points 155-177m. Figure 1 shows a stratigrphic vertical column Figure 5, in which two coarsening-upward cycles have been detected postulating a shallowing-upward sequences reflecting a relatively regression phase during Early Oligocene.

These recorded cyclic sequences and their representative units can be described as following:

Unit (1)

Consists of mudstone texture, moderately hard to hard, white color. The beds are very thick with some benthic forams, and Nummulites, sp. The thickness of this unit is about $2.5 \mathrm{~m}$

Unit (2)

It consists of wackstone, medium grained, hard, white color, thickly bedded, poor-fair porosity with some calcareous algae. The thickness of this unit is $3.5 \mathrm{~m}$.

\section{Unit (3)}

It consists of pack stone, medium grained, hard, white color, very thickly bedded contains Quinquloclina with some porosity, with some algal balls, attaining a thickness of $2.5 \mathrm{~m}$.

Unit (4)

It consists of grainestone, medium to coarse grained, hard, white color, wavy bedding, porous, and attaining a thickness of about $3 \mathrm{~m}$.

\section{Unit (5)}

This unit consists of mudstone texture, moderately hard to hard, white color, thickly bedded, poor porosity, with some coralline algae The thickness of this unit is $2 \mathrm{~m}$.

\section{Unit (6)}

It consists of wackstone, medium grained, hard, white color, very thickly bedded poor-fair porosity. The thickness of this unit is $3.5 \mathrm{~m}$.

\section{Unit (7)}

It consists of packstone, medium grained, hard, white color very thickly bedded, fair-good porosity, contains algal ball and Nummulites sp, attaining a thickness of $3.5 \mathrm{~m}$.

\section{Unit (8)}

It consists of grainestone, medium to coarse grained, hard, white color. very thickly bedded, good porosity with coralline algae, some Nummulites sp and fine shell fragments (skeletal materials). The thickness of this unit is $3.5 \mathrm{~m}$.

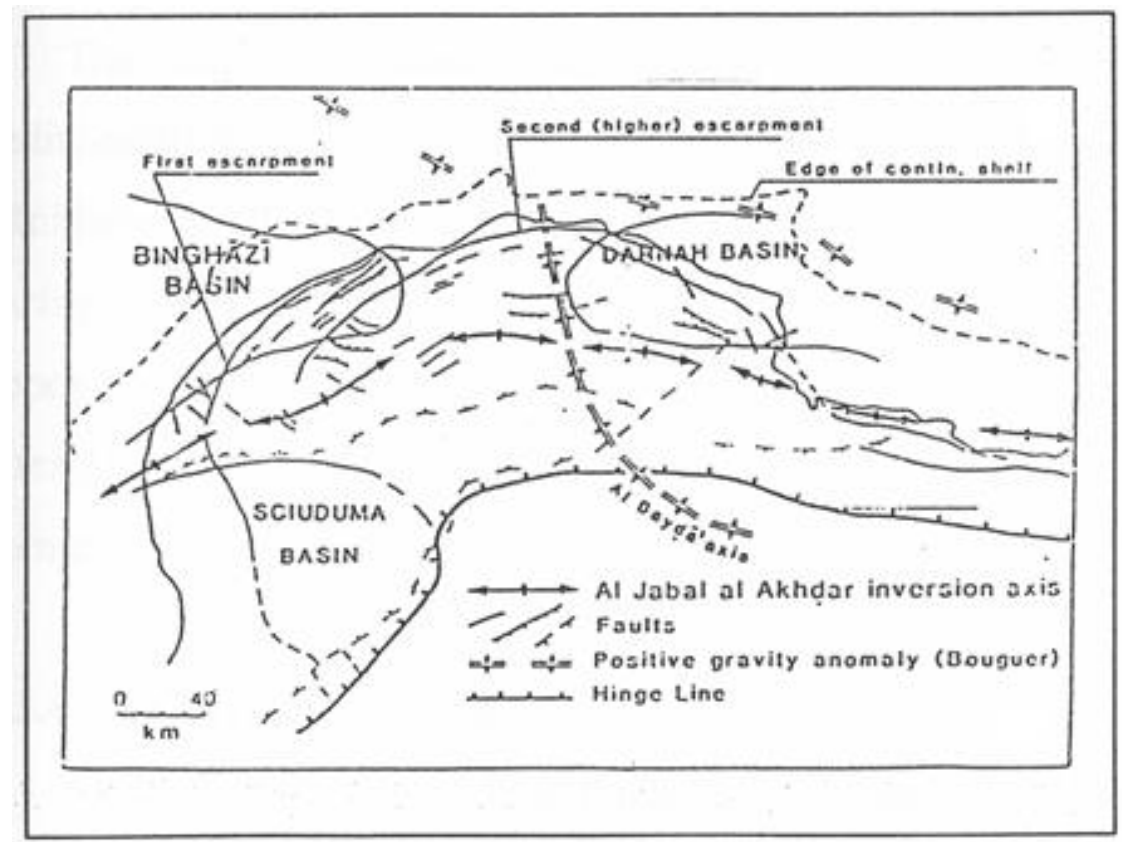

Figure2. Structure map of Al Jabal Al Akhdar, showing the extend of the two escarpments. From [8] 


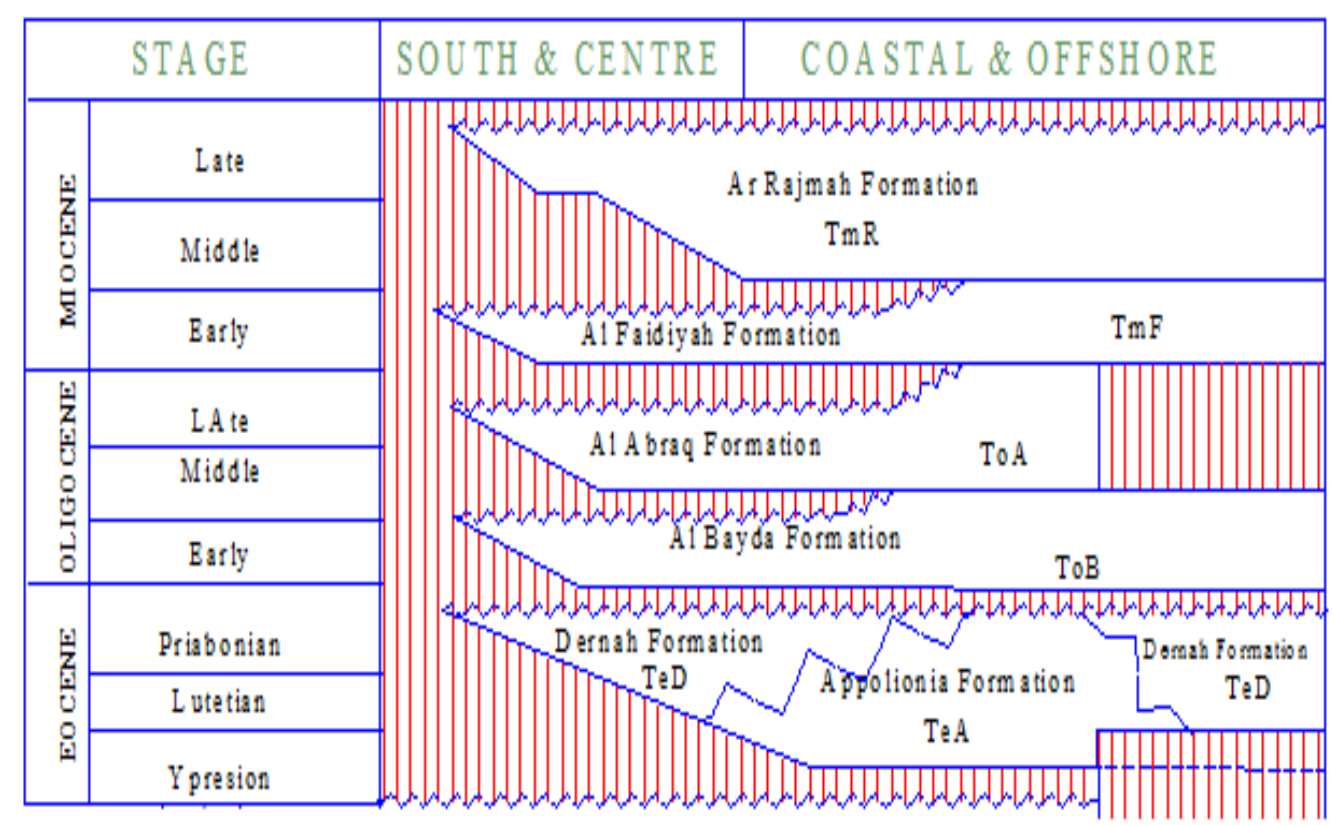

Figure3. Stratigraphic chart of Al Jabal Al Akhdar, NE Libya. From [12]

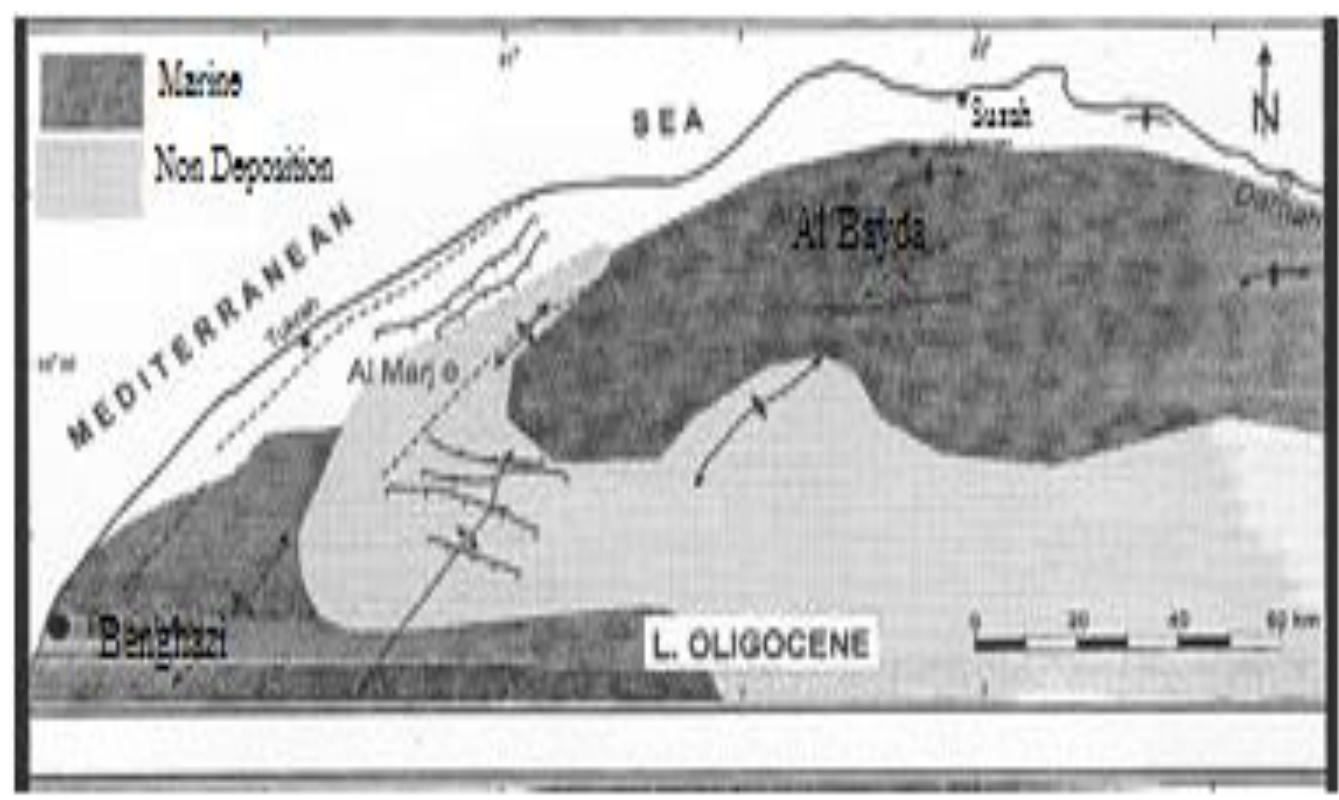

Figure4. Lower Oligocene paleogeography of Al Jabal Al Akhdar region, extend of Al Bayda Formation. From [14].

\section{Methodology}

The samples studied are from the Algal Limestone Member at the vicinity of Wadi Al Buwayrat, which was collected from a stratigraphic traverse Figure 1. Construction of stratigraphic column Figure 5 of defined (8) rock units composing the studied escarpment

Ten (10) samples for which porosity and permeability were determined with $2 \mathrm{~cm} \times 2.5 \mathrm{~cm}$. dimensions.

Grain density measurements were also obtained for the investigated plugs. Rock plugs were cut using rotary core cutting machine Figure 6.

Total Rock plug porosity $\left(\emptyset_{t}\right)$ was measured by helium injection using Boyle's law Corex Helium Prosimeter at AGOCO Lab. Figure 7, with bulk volume determined by calliper.

Permeability values were obtained using Corex Nitrogen permeameter at AGOCO Lab with confining pressure of approximately 20 bar Figure 8. 
Porosity-Permeability Relationships in the Early Oligocene Algal Limestone Member of Wadi Al Buwayrat, Tansolukh Area, Al Jabal Al Akhdar, NE Libya

Ten (10) rock thin sections were cut from the same rock plugs for petro graphic studies and determination of the macro porosity $\left(\emptyset_{\mathrm{m}}\right)$ (thin-section porosity). Cross-plots graphic representation between porosity types and permeability values were obtained for comparison.

In general, these units were examined and taken from the algal limestone member of Al Bayda Formation (Early Oligocene). The oncolites of red algae genus Lithothamnium consists a distinctive percentage of these units, in addition to large nummulites $(>2 \mathrm{~mm}$.), mollusca shells and echinoderm fragments and some benthic forams. All these constituents are embedded in micrite and some little of microsparite cement. The general facies types recognized in the stratigraphic column Figure 5 reveal that the studied Algal Limestone have deposited in two coarsening-upward cycles (cycle 1 and 2) in which facies sequences have graded from basal fore reefal shelf facies of mudstone texture to upper algal/keletal reefal complex facies of mainly packstone-grainstone texture. This association of fauna and lithology suggests deposition in foreslope and shoal of platform edge recommended by Rohlich (1974) and Abdulsamad (1998) [15, 16].

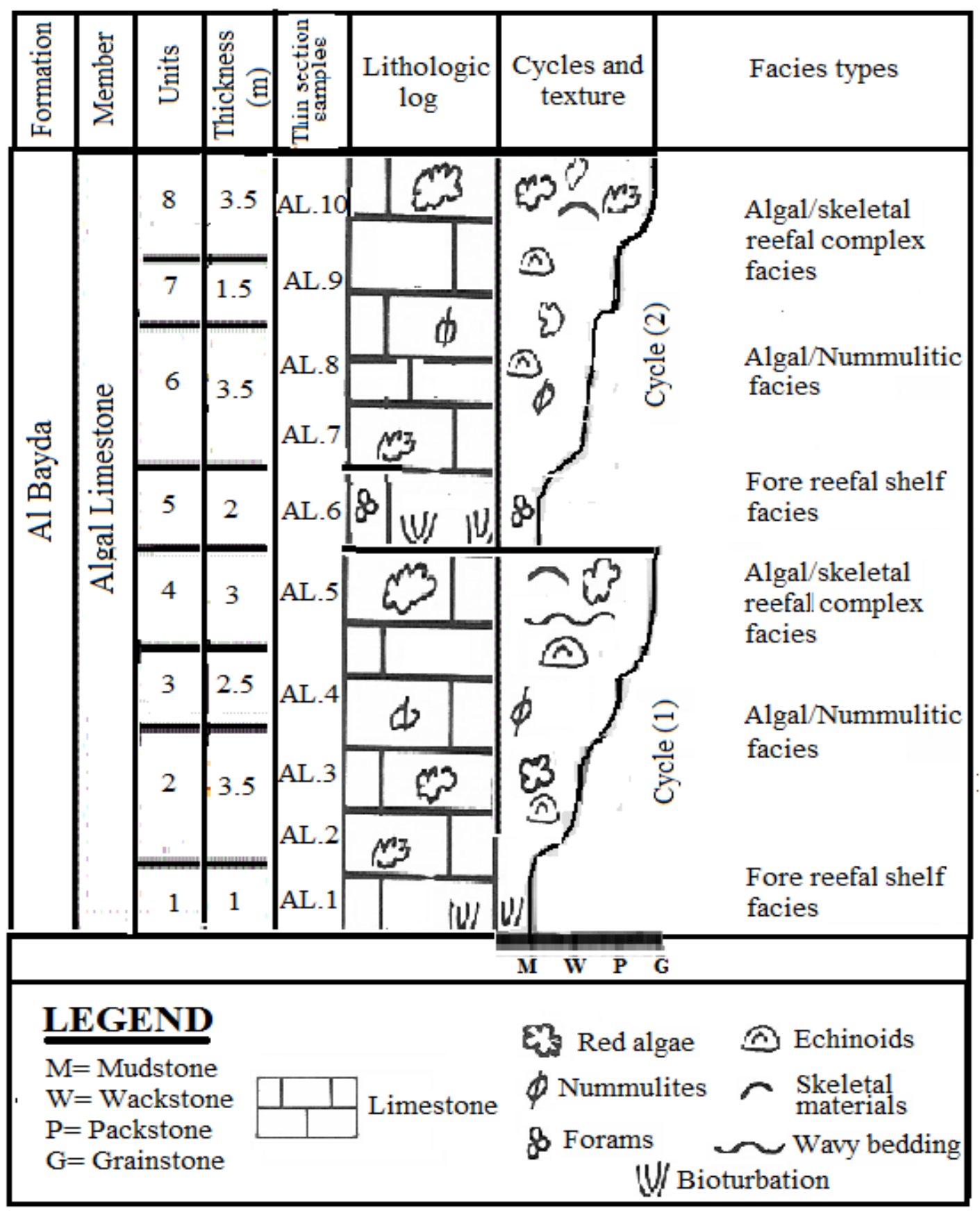

Figure5. Stratigraphic column of Algal Limestone Member in the study area 



Figure6. Rotary core cutting machine at AGOCO Lab

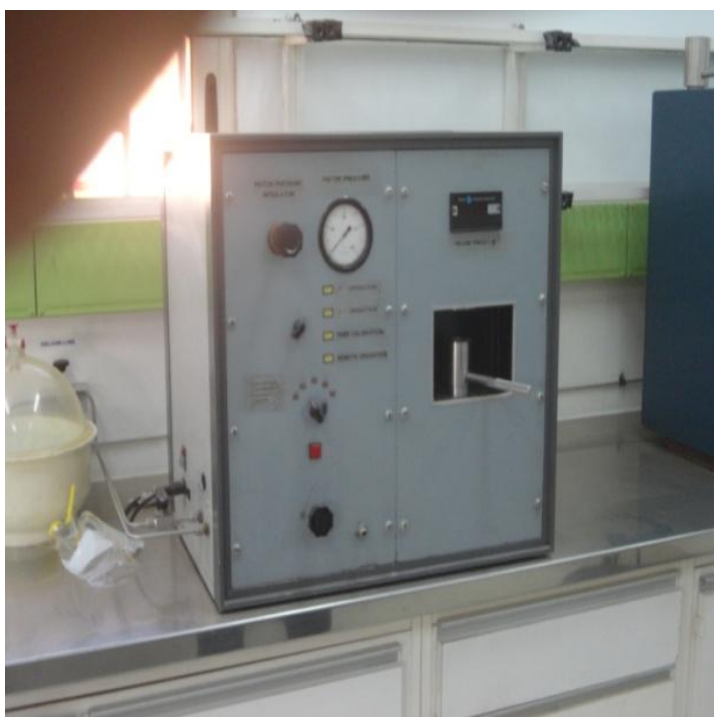

Figure7. Corex Helium Porosimeter at AGOCO Lab

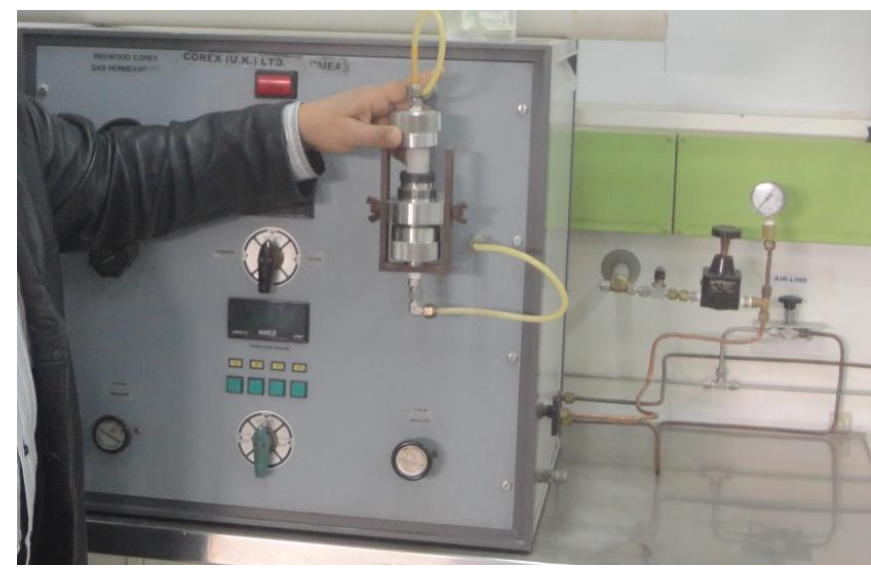

Figure8. Corex Nitrogen Permeameter at AGOCO Lab

\section{Definitions}

Total porosity is defined as the fraction of the bulk rock volume (V) that is not occupied by solids matter [17]. If the volume of solids is denoted by Vs and the pore volume is $\mathbf{V p}=\mathbf{V}-\mathbf{V s}$, we can write the porosity as:

$\varnothing=\frac{\mathrm{V}-\mathrm{Vs}}{\mathrm{V}}=\frac{\mathrm{Vp}}{\mathrm{V}}=\frac{\text { pore value }}{\text { total rock value }}$

Total porosity could also be defined as core/rock plug helium porosity representing (macro porosity and micro porosity), [18]. 
Macro porosity: Effective and connected thin-section measurable porosity. Also can be defined as the percentage pore area measured on the thin section image versus total porosity measured on the plug volume [19].

Micro porosity: Porosity resident in small pores $(<2 \mu \mathrm{m})$ commonly associated with detrital or authigenic clays.

Permeability: Is the measure of the ability of porous media to transmit fluids. Its unit of measurement is the Darcy.

\section{Data Analysis}

\section{(A) Laboratory determination of porosity:}

Through gas expansion method (helium porosimeter), the Porosimeter at AGOCO core Lab. Figure 9 was used, which relies on the ideal gas law ,or rather Boyle's law $\left(\mathrm{P}_{1} \mathrm{~V}_{1}=\mathrm{P}_{2} \mathrm{~V}_{2}\right)$. Two chambers of known volumes $\left(\mathrm{V}_{1}\right.$ and $\left.\mathrm{V}_{2}\right)$ were connected, one containing helium as a gas phase at a given pressure of $\left(\mathrm{P}_{1}\right)$ and another contains a rock plug of Algae Limestone at atmospheric pressure $\left(\mathrm{P}_{2}\right)$.

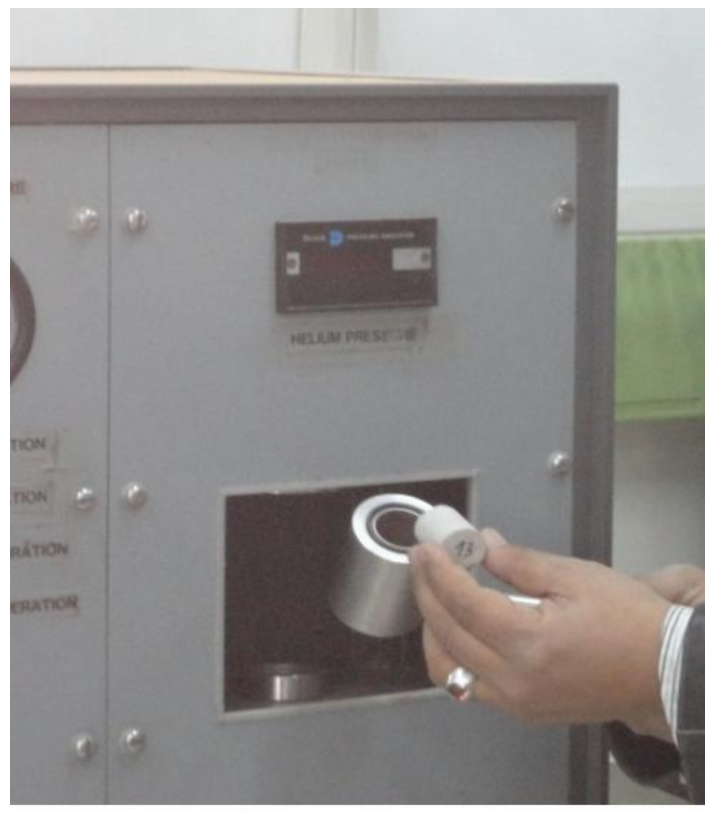

Figure9. Total porosity analysis of rock plug using helium porosity (AGOCO-Lab)

The helium is expanded into the sample chamber and an equilibrium pressure $\left(\mathrm{P}_{2}\right)$ is recorded. The initial volume $\left(\mathrm{V}_{1}\right)$ of the helium chamber is known, thus the volume of the new system helium chamber $\left(\mathrm{V}_{2}\right)$ is determined using boyle's law. By subtracting $\mathrm{V}_{1}$ from $\mathrm{V}_{2}$ the total pore volume $\left(\mathrm{PV}_{\mathrm{t}}\right)$ for the given rock plug is obtained. The rock-plug total porosity $\left(\varnothing_{t}\right)$ is simply the fraction between the total pore volume $\left(\mathrm{PV}_{\mathrm{t}}\right)$ and the rock plug bulk volume $\left(\mathrm{V}_{\mathrm{b}}\right)$

$\emptyset_{\mathbf{t}}=\mathbf{P V} \mathbf{V}_{\mathbf{t}} / \mathbf{V}_{\mathbf{b}}$

The bulk volume of the rock is determined before the experiment by using either vernier callipers and assuming that the sample is perfectly cylindrical, or by fluid displacement using the saturated sample. Total porosity measurements for the ten selected plug samples from the Algal Limestone can be obtained and listed in Table 1. This method is rapid, very accurate, insensitive of mineralogy, and leaves the sample available for further testing.

Grain density $\left(\mathrm{G}_{\mathrm{d}}\right)$ for each rock plug is a function of the weight of the clean dry sample to its grain volume. grain volume $\left(\mathrm{G}_{\mathrm{v}}\right)$ is obtained by subtracting total pore volume $\left(\mathrm{PV}_{\mathrm{t}}\right)$ from the bulk volmue $\left(\mathrm{V}_{\mathrm{b}}\right)$ for each plug sample $\mathrm{G}_{\mathrm{v}}=\mathrm{V}_{\mathrm{b}}-\mathrm{V}_{\mathrm{t}}$

$\mathbf{G}_{\mathrm{d}}=\frac{\text { weight of dry sampels }}{G v}$

\section{(B) Laboratory Determination of Permeability through Permeameter:}

The rock plug samples of $2 \mathrm{~cm}$ and $2.5 \mathrm{~cm}$ diameters were used to measure permeability $(\mathrm{K})$ of the different lithofacies for the examined section from the Algal Limestone Membar, Wadi Albuwayrat. 
Corex Nitrogen Pemeameter at AGOCO Core Lab. Figure 10 was used to measure permeability (K) values for the selected limestone samples. Permeability values are listed in Table $\mathbf{1 .}$

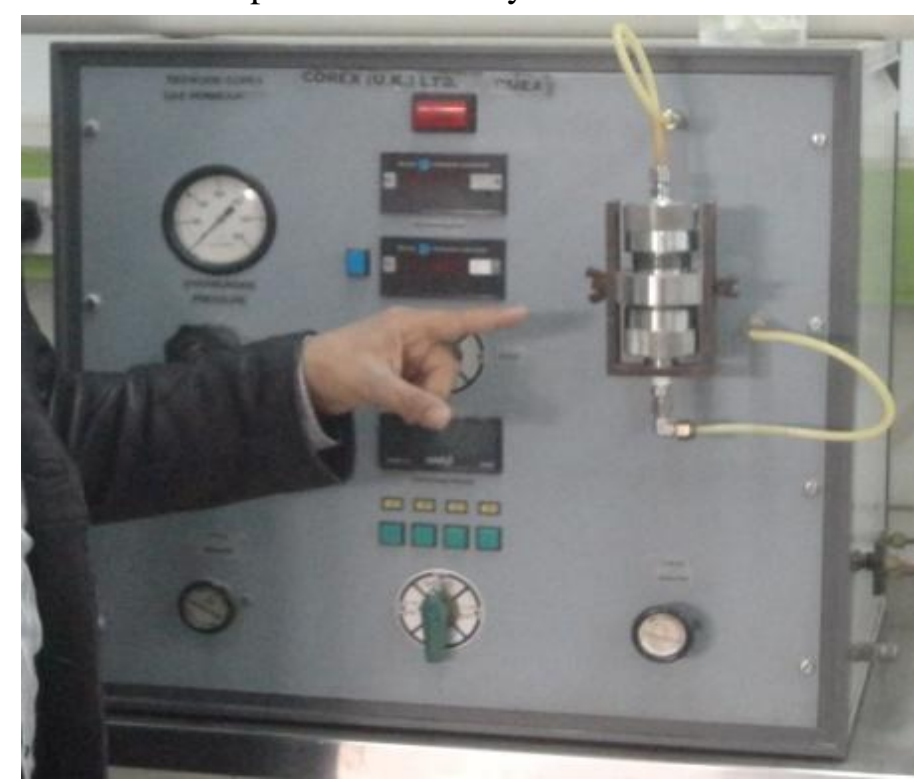

Figure10. Permeability analysis of rock plug using Nitrogen Permeameter in AGOCO Lab.

Table1. Rock-plug total porosity $\left(\emptyset_{t}\right)$ and permeability $(K)$ for the studied samples (AL.1-AL10) measured by porosimeter and permeameter at AGOCO Lab.

\begin{tabular}{|c|c|c|c|}
\hline Sample No. & Air permeability $(\mathrm{K}) \mathrm{md}$ & Rock-plug total porosity $\left(\emptyset_{\mathrm{t}}\right) \%$ & Grain density $\left(\mathrm{g} / \mathrm{cm}^{3}\right)$ \\
\hline AL.1 & $\mathbf{0 . 0 1 9}$ & $\mathbf{2 . 6 8}$ & $\mathbf{2 . 7 0}$ \\
\hline AL.2 & $\mathbf{0 . 0 1 1}$ & $\mathbf{5 . 4 5}$ & $\mathbf{2 . 6 9}$ \\
\hline AL.3 & $\mathbf{0 . 0 2 1}$ & $\mathbf{8 . 2 7}$ & $\mathbf{2 . 6 7}$ \\
\hline AL.4 & $\mathbf{1 9 . 6 2}$ & $\mathbf{1 2 . 6 4}$ & $\mathbf{2 . 6 5}$ \\
\hline AL.5 & $\mathbf{3 . 9 0}$ & $\mathbf{2 1 . 2 8}$ & $\mathbf{2 . 7 0}$ \\
\hline AL.6 & $\mathbf{5 . 7 8}$ & $\mathbf{3 . 8 2}$ & $\mathbf{2 . 7 0}$ \\
\hline AL.7 & $\mathbf{1 . 3 2}$ & $\mathbf{7 . 6 7}$ & $\mathbf{2 . 6 5}$ \\
\hline AL.8 & $\mathbf{0 . 7 6}$ & $\mathbf{9 . 6 8}$ & $\mathbf{2 . 7 1}$ \\
\hline AL.9 & $\mathbf{3 . 5 8}$ & $\mathbf{1 2 . 5 4}$ & $\mathbf{2 . 7 0}$ \\
\hline AL.10 & $\mathbf{7 . 1 8}$ & $\mathbf{2 6 . 8 9}$ & $\mathbf{2 . 6 8}$ \\
\hline
\end{tabular}

(C) Petrographic Study of Porosity Types

Petographic study for ten (10) thin sections (AL.1-AL.10) from Algal Limestone plugs was conducted to point-count macroporosity $\left(\emptyset_{\mathrm{m}}\right)$ (thin section porosity), Table 2 , inter and intra-skeletal macroporosity were identified by means of their size, shapes and their dissolution features. Most samples are mainly composed of carbonate, but few samples have some quartz, phosphate and glauconite grains. Mineralogic proportions were mainly estimated qualitatively from the studied thin sections.

Secondary porosities are much dominating the studied thin- section which could be classified through petographic examination of (10) thin sections as following:

(1) Interskeletal porosity, (2) Intraskeletal porosity, (3) Cement leaching porosity, and (4) Moldic and larger vuggy porosity that formed by moulds of dissolved bioclasts.

Based on the relative abundances and sizes of these pore types and their association with each facies in each studied cycle, the samples were grouped in four textural categories Figure 11 and Figure 12.

- Mudstone: The pore system is dominated by interskeletal micropores within mud (micritic) matrix and unconnected intra microfossils (Figure 11 AL.1 and Figure 12 AL.6). The samples in this group are all from the basal fore-reefal shelf muddy facies.

- Wackstone: The pore system is dominated by small interskeletal in very fine-grained texture $(0.5 \mathrm{~mm})$ (Figure 11 AL.2, AL.3 and Figure 12 AL.7, AL.8). However, exceptions included in this group are samples with similar depositional textures, but with partial leaching of micrite filling pores (Figure 11 AL.3 and Figure 12 AL.8). The samples in this group are all from the transitional algal/nummulitic foreslope facies. 
Porosity-Permeability Relationships in the Early Oligocene Algal Limestone Member of Wadi Al Buwayrat, Tansolukh Area, Al Jabal Al Akhdar, NE Libya

- Packstone: The pore system is dominated by small interskeletal and intraskeletal pores in finegrained $(<1 \mathrm{~mm})$ imbedded in micritic texture of packstone, partial sparite and bioclastic leaching porosities are also common (Figure 11 AL.4 and Figure 12 AL.9). The samples in this group are all from the top most transitional algal/nummulitic or upper-shelf slope facies.

- Grainstone: The pore system is dominated by large interskeltal macropores in coarse-grained $(>1$ $\mathrm{mm}$ ) grainstone texture (Figure 11 AL.5 and Figure 12 AL.10) These samples are characterized by moldic to vuggy porosity occasionally with heavily leached sparite cement. The samples in this group are all from the algal/skeletal reefal complex facies.

Table2. Thin-section porosity- macroporosity $\left(\varnothing_{m}\right)$, total rock plug porosity $\left(\varnothing_{t}\right)$ and permeability $(K)$ of studied thin section samples (AL.1-AL.10) of Algal Limestone Member.

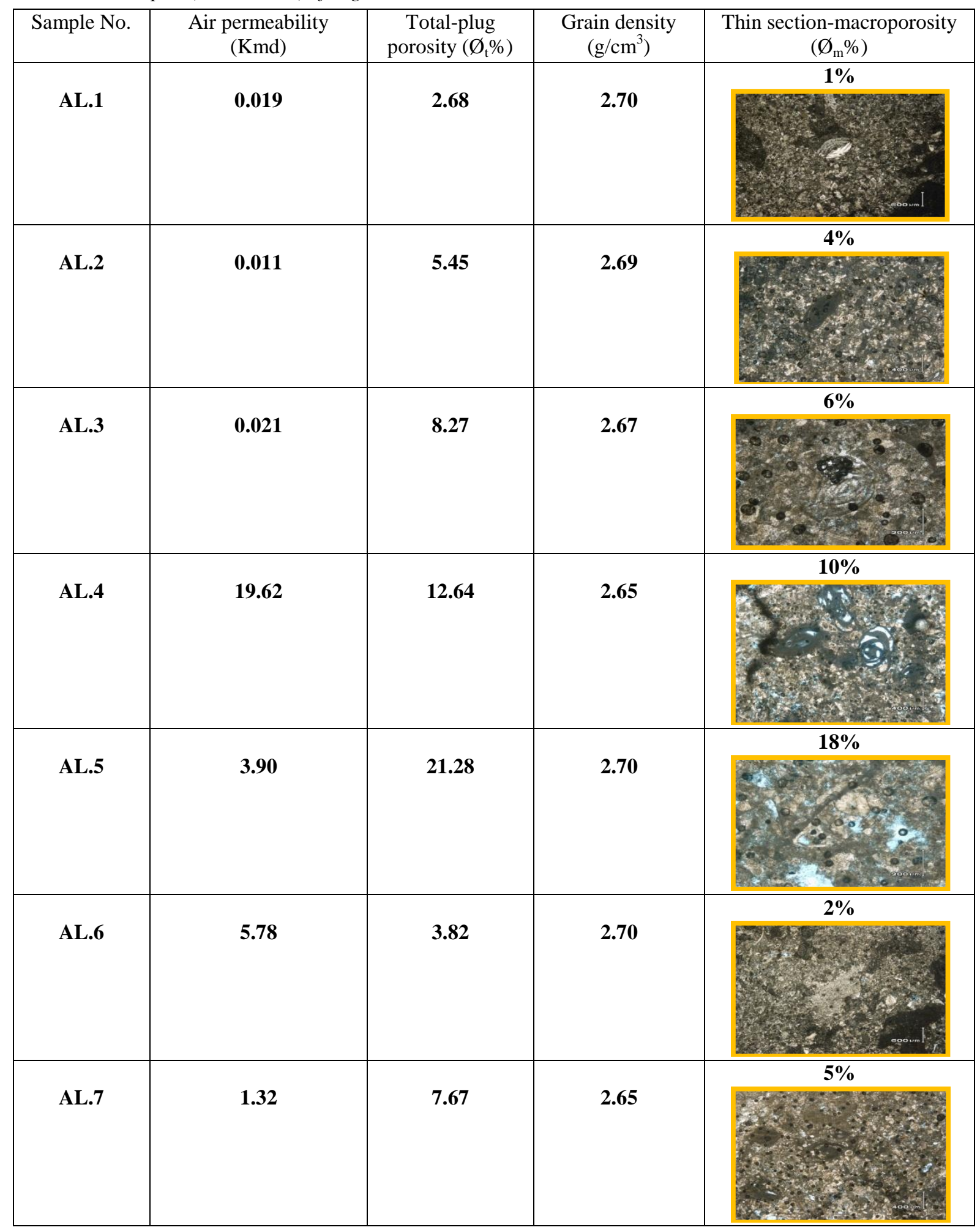


Omar B. Elfigih \& Ebrahim A. Al-Orabi

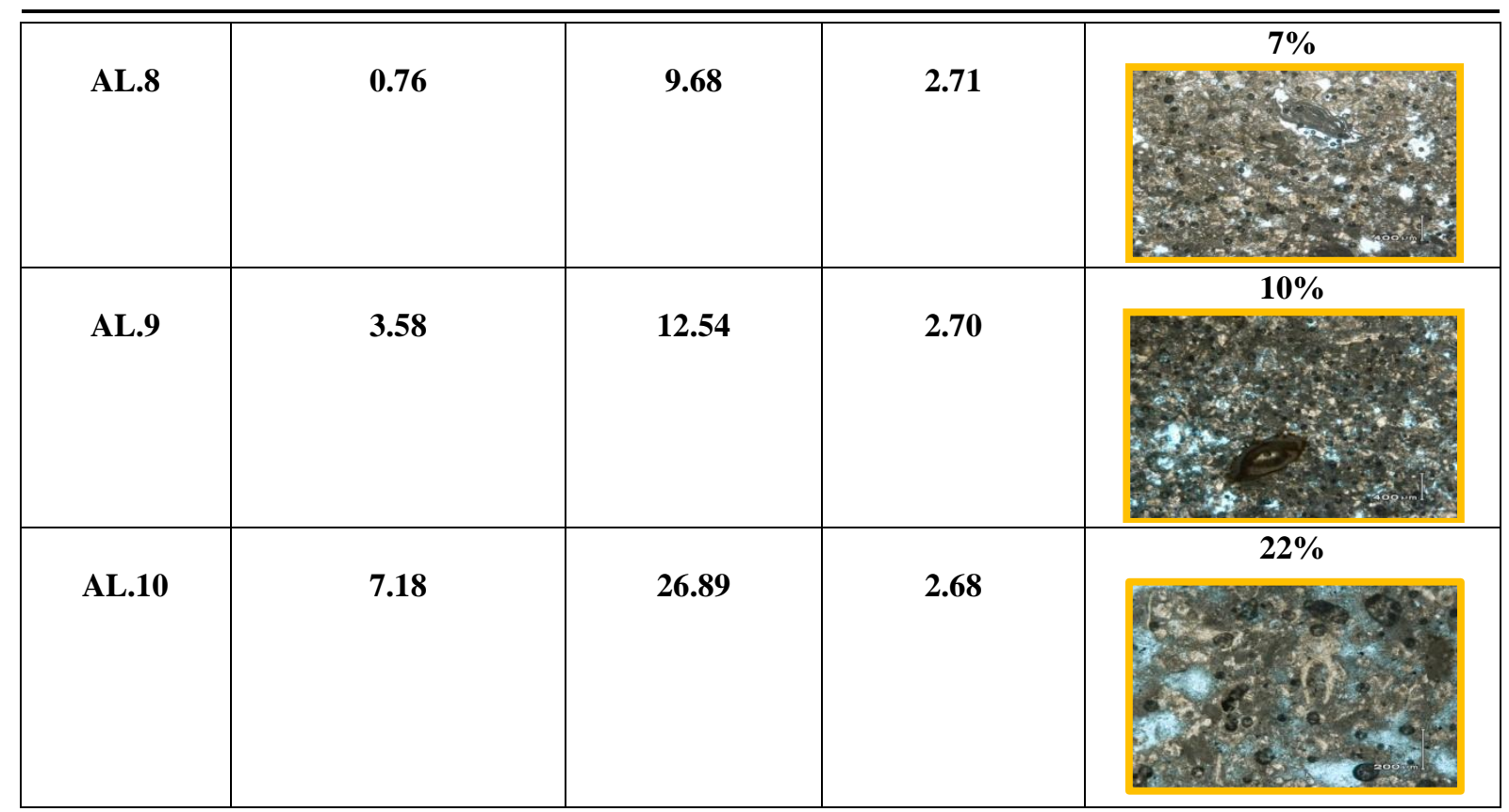
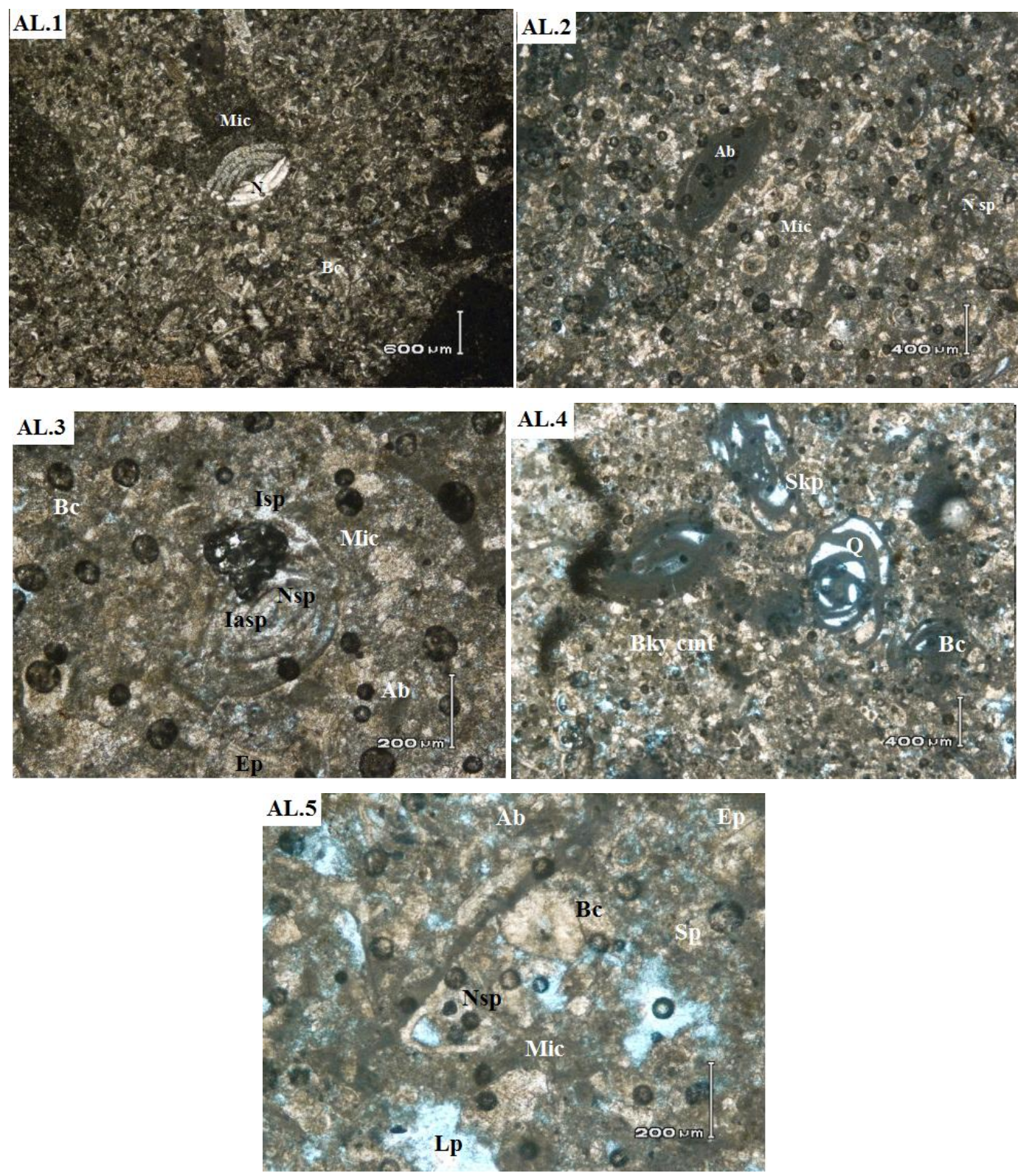

Figure11. Photomicrographs of Algal limestones in cycle(1). Blue areas if present are epoxy-impregnated porosity. (AL.1) Mudstone texture consists of bioclasts (Bc), Nummulites (N) with micritic matrix (Mic), 
Porosity-Permeability Relationships in the Early Oligocene Algal Limestone Member of Wadi Al Buwayrat, Tansolukh Area, Al Jabal Al Akhdar, NE Libya

compacted with intensive micratization, poor macro porosity $\left(\emptyset_{m}\right)$ and total plug porosity $\left(\emptyset_{t}\right)(1 \%$ and $2.68 \%)$ and poor permeability $(0.019 \mathrm{md})$. (AL.2) Wackstone texture, allochems types are of bioclasts (Bc) of mainly Algal balls (Ab), and Nummulites sp. (Nsp), embedded in micritic matrix (Mic) with partial calcite cement, poor inter-skeletal porosity (Isp). Poor macro porosity $\left(\varnothing_{m}\right)$ and total plug porosity $\left(\varnothing_{t}\right)(4 \%$ and $5.45 \%)$ and poor permeability (0.011md). (AL.3) Wackstone texture composed of bioclats $(B c)$ mainly representing Algal balls (Ab), Nummulites sp (Nsp) and some Echinoid plates (Ep) fragments, micritic matrix occasionally of pore-filling micrite with partial matrix dissolution, poor inter- and intra-skeletal porosity (Isp and Iasp). Poor macro porosity $\left(\varnothing_{m}\right)$ and total plug porosity $\left(\varnothing_{t}\right)(6 \%$ and $8.27 \%)$ and of poor permeability $(0.021 \mathrm{md})$. (AL.4) Packstone texture, consists of variety of bioclasts (Bc); Algal balls (Ab), Quinqueloculina (Q), with blocky calcite cement (Bky cmt) that partly to completely filled pore space. However small inter-skeletal and intraskeletal porosities (Skp) are very common caused by leaching sparite cement. In general this rock type is characterized by fair macro porosity $\left(\emptyset_{m}\right)$ and total plug porosity $\left(\emptyset_{t}\right)(10 \%$ and $12.64 \%)$ and fair permeability $(19.62 m d)$.

(AL.5) Grainstone texture, allochems types of mainly bioclasts (Bc) represented mainly by Algal balls (Ab), Echinoid plates (Ep) fragments and some Nummulites sp (Nsp), with partial pore-filling sparite (Sp). Sparite dissolution to produce leaching porosity $(\mathrm{Lp})$ is very common. Good macro porosity $\left(\emptyset_{m}\right)$ and total plug porosity $\left(\emptyset_{t}\right)(18 \%$ and $21.28 \%)$ with poor permeability $(3.90 \mathrm{md})$ as the very fine grained sparite cement surrenders pores.
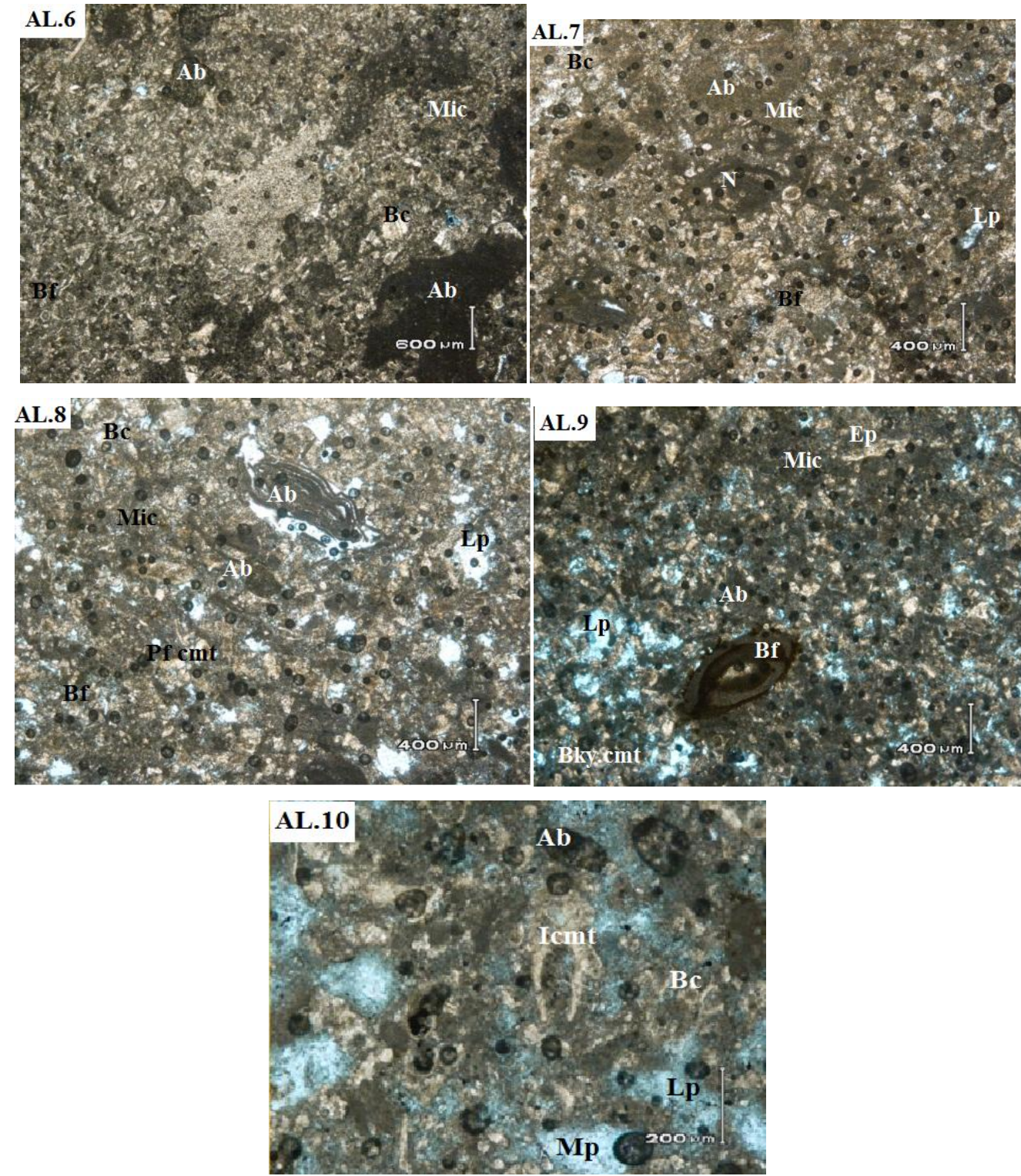

Figure12. Photomicrographs of Algal limestones in cycle (2). Blue areas if present are epoxy-impregnated porosity. (AL.6) Mudstone texture rich in bioclasts (Bc); Algal balls (Ab), with some Benthic forams (Bf), micritic (Mic), poor macro porosity $\left(\emptyset_{m}\right)$ and total plug porosity $\left(\emptyset_{t}\right)(2 \%$ and $3.82 \%)$, poor permeability (5.78md). (AL.7) Wackstone texture, bioclasts are of Algal balls (Ab), Benthic forams (Bf) and Nummulites sp 
$(N)$, micritic matrix (Mic), partial leaching (Lp), pore filling micrite (Mic) where partial micritic cements binding this rock however if there are spar cements they are very fine grained in fact most of the cement appears to be micrite at points of contact are meniscus cements. Poor macro porosity $\left(\emptyset_{m}\right)$ and total plug porosity $\left(\emptyset_{t}\right)(5 \%$ and $7.67 \%)$ and poor permeability $(1.32 \mathrm{md})$. (AL.8) Wackstone texture, Allochems types are mainly Bioclasts $(B c)$; rich in Algal balla $(A b)$ and some Benthic forams $(B f)$, embedded in micritic matrix (Mic). However isopachous cement (I.cm) and pore-filling sparite (Pf.cmt) are common. Partial leaching of calcite-filling pores $(\mathrm{Lp})$ and/or moldic porosity, poor-fair macro porosity $\left(\emptyset_{m}\right)$ and total plug porosity $\left(\emptyset_{t}\right)(7 \%$ and $9.68 \%)$ and of poor permeability $(0.76 \mathrm{md})$. (AL.9) Packstone texture rich in allochems of bioclasts types such as Algal balls (Ab), Benthic forams (Miliolids) (Bf) and some Echinoid plates (Ep) fragments, blocky aparitic cement (Bky.cmt) is common, with some micritic matrix (Mic), with leaching sparite to partial leaching bioclasts porosity (Lp). Fair to good macro prosity $\left(\emptyset_{m}\right)$ and total plug porosity $\left(\varnothing_{t}\right)(10 \%$ and $12.54 \%)$ but with poor permeability (3.58md) as micritic matrix (Mic) reduces connected pore spaces. (AL.10) Grainstone texture composed of bioclasts $(B c)$ represented mainly by Algal balls (Ab), isopacheous cement (I.cmt) is very pronounced, with heavy leached sparite cement ( $L p)$ which may enhance vuggy porosity, and of moldic porosity $(M p)$. Good to very good macro porosity $\left(\emptyset_{m}\right)$ and total plug porosity $\left(\emptyset_{t}\right)(22 \%$ and $26.89 \%)$ with fair to good permeability (7.18md).

\section{(D) Graphic Representation to Show Relationship between Porosity and Permeability}

Analysis of available samples permits listing of measured total and macro porosity along with permeability readings Tables 1 and Table 2 .

The relationship between observed porosity types (total porosity $\varnothing_{\mathrm{t}}$ and macro porosity $\varnothing_{\mathrm{m}}$ ) and the bulk permeability $(\mathrm{K})$ of the selected units in the Algal Limestone Member can be seen by using graphic representations Figure 13, Figure 14 and Figure 15. In Figure 13, points below line of general high macro porosity $\left(\varnothing_{\mathrm{m}}\right)$ up to $18 \%$, with general decrease in permeability ( $\left.0.26-3.90 \mathrm{md}\right)$ representing muddy-calcite cement facies, whereas points above line show general high porosity (10$22 \%)$ and of high permeability (6-19 md) representing much vuggy packstone-grainstone texture with connected pore spaces. Total rock plug porosity $\left(\varnothing_{t}\right)$ versus permeability show no correlation between studied samples Figure 13.

Figure 14 reveals some correlation between total core plug porosity $\left(\varnothing_{t}\right)$ and thin section porosity (macro porosity $\varnothing_{\mathrm{m}}$ ) where deviation of the points to the right of the correlation line indicates the amount of micro porosity present which associated with more matrix or limemud.

Macro porosity $\left(\varnothing_{\mathrm{m}}\right)$ or (thin-section porosity) versus permeability $(\mathrm{K})$ Figure 15 is showing random distributions of porosity/permeability values, and a general lack of correlation between studied points.

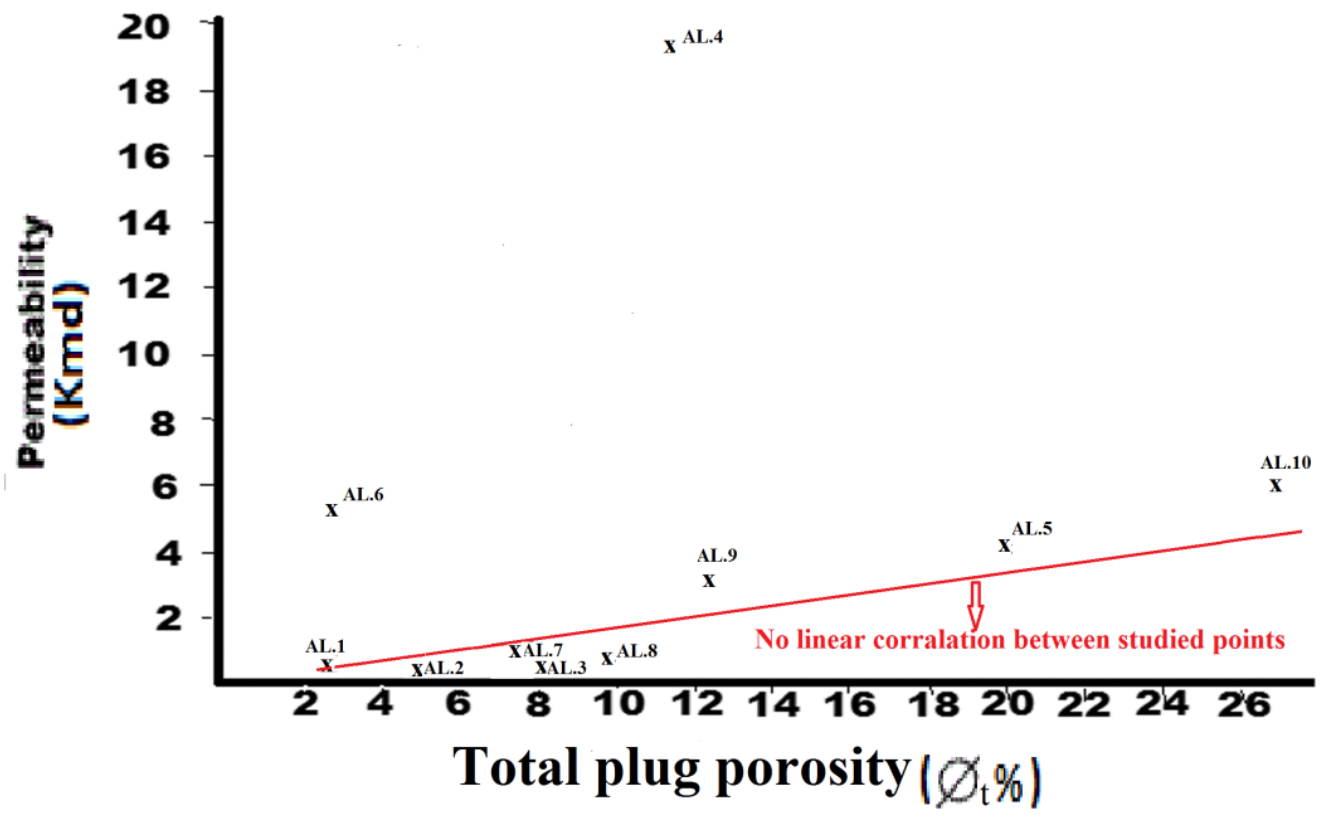

Figure13. Total rock plug porosity $\left(\emptyset_{t}\right)$ versus permeability $(K)$ of the studied samples (AL.1-AL.10) of Algal Limestone Member, Wadi AlBuwayrat, Tansolukh area, Al Jabal Al Akhdar, Libya 




Figure14. Total rock plug porosity $\left(\emptyset_{t}\right)$ versus thin section macroporosity $\left(\emptyset_{m}\right)$ of the studied samples (AL.1AL.10) of Algal Limestone Member, Wadi AlBuwayrat, Tansolukh area, Al Jabal Al Akhdar, Libya



Figure15. Macroporosity $\left(\emptyset_{m}\right)$ versus permeability $(K)$ of the studied samples (AL.1-AL.10) of Algal Limestone Member, Wadi AlBuwayrat, Tansolukh area, Al Jabal Al Akhdar, Libya

\section{Conclusions}

Comparison of rock plug porosity -permeability measurements with that of thin-section petrography and sedimentologic data provides a comprehensive basis for describing the petrophysical (porosity and permeability) characteristic of the Early Oligocene, Algal Limestone Member in Tansolukh area, Al Jabal Al Akhdar and interpreting the controlling factors involved.

Overall high porosity and permeability of these strata reflects the dominantly coarse bioclastic texture and the presence of early isopachous calcite cement, which may have inhibited compaction.

The Algal Limestone samples display wide variation in both total porosity and porosity-permeability trend ( i.e. permeability -for-given-porosity) that are clearly related to depositional and diagenetic characteristics including mud content, grain size and cement volume. Some limestone samples however, tend to plot along a more limited porosity-permeability trend regardless of whether textures are dominated by preserved intergranular pores, intercrystalline pores or vugs . This general lack of correlation between porosity types and permeability is interpreted as reflecting recrystallization of 
mud matrix (micritization ) to form intercrystalline macroporosity $\left(\varnothing_{\mathrm{m}}\right)$ that connects vugs as part of the effective pore system.

This study provides a well -documented example of extreme petrophysics (porosity -permeability) heterogeneity in shallowly carbonate setting having a relatively simple diagenetic history.

\section{ACKNOWLEDGMENTS}

The authors would like to thank the Department of Earth Sciences, University of Benghazi for providing most of the data used in this study. I am grateful to AGOCO Laboratory staff for their generous help for providing me unlimited access to the porosity-permeability facilities through preparation of rock plugs, thin sections and their analysis. Deep thanks are also extended to anonymous reviewers for their constructive comments and thoughtful discussions on this paper.

\section{REFERENCES}

[1] Saller, A. H., and N. Henderson (1998), Distribution of porosity and permeability in platform dolomites: Insight from the Permian of west Texas AAPG Bulletin, v. 82, p. 1528- 1550.

[2] Ehrenberg, S. N. (2004a), Porosity and permeability in Miocene carbonate platforms on the Marion Plateau, offshore NE Australia: Relationships to stratigraphy, facies and dolomitization, in C. J. R. Braithwaite, G. Rizzi, and G.Darke, eds., The geometry and petrogenesis of dolomite hydrocarbon reservoirs: Geological Society (London) Special Publication 235, p. 233- 253.

[3] Ehrenberg, S. N., G. P. Eberli, and G. L. Bracco Gartner, (2004b), Data report: Porosity and permeability of Miocene carbonate platforms on the Marion Plateau, ODP Leg 194, in F. S. Anselmetti, A. R. Isern, P. Blum, and C. Betzler, eds., Proceedings of the Ocean Drilling Program, Scientific Results, v. 194, available at: http://www-odp.tamu.edu/publications /194_SR/007/

007.htm

[4] Ehrenberg S. N., Eberli G. P., Keramati M., and Moallemi S. A. (2006), Porosity- permeability relationships in interlayered limestone-dolostone reservoirs, AAPG Bulletin, v. 90, no. 1 (January 2006), pp. 91-114.

[5] Baker H. A., AL-Jawad S. N. and Murtadha Z. I. (2013), Permeability Prediction in Carbonate Reservoir Rock Using FZI, Iraqi Journal of Chemical and Petroleum Engineering (IJCPE) Vol.14 No.3 (September 2013) p.49- 54.

[6] AlRatrout A. A., Kalam M. Z., Gomes J. S. and Jouini M. S. (2014), Assessing Microporosity in Carbonate Reservior Using Digital Rock Physics (DRP) and Other Established Techniques, i.e. MICP, NMR, TS and BSEM (Abs.), AAPG Annual Convention and Exhibition, Houston, TX.

[7] Rahmouni A., Boulanouar A., Boukalouch M., Géraud Y., Samaouali A., Harnafi M., Sebbani J. (2014), Relationships between porosity and permeability of calcarenite rocks based on laboratory measurements, In: J. Mater. Environ. Sci. 5 (3) (2014) 931-936.

[8] Desio, A. (1971), Outlines and problem in the geomorphological evolution of Libya, from the Tertiary to the present day. In: Symp. Geol. Libya (ed. C. Gray), Fac. Sci., Univ. Libya, Tripoli, 11-36.

[9] Kleinsmiede, W.F.J. and Van Den Berg N. J. (1968), Surface geology of the Jabal Al Akhdar, Northern Cyrenica, Libya. In: Geology and Archeology of Northern Cyrenica, Libya, Petrol. Expl. Soc. Libya, $10^{\text {th }}$ Annual Field conf.

[10] Goudarzi, G.H. (1978), Structure-Libya. In M.J.Salem and M.T. Buserwil (Eds.), Geology of Libya, Academic Press, London., 1980, 3, 879 -892 .

[11] Rohlich, P. (1980), Geological development of Al Jabal al Akhdar, Libya, Geol. Roundsch., 67, 401-412.

[12] El Hawat, A.S. and Shelmani, M.A. (1993), Short notes and guidebook on the geology of Al Jabal al Akhdar, Cyrenica, NE Libya Sedimentary basins of Libya, Sirte Basin, 70.

[13] El Hawat, A.S. (1997), Sedimentary basins of Egypt: An overview of dynamic Sedimentary Basins of the World, edited by R.C.Selley (Series Editor, K.J.Hsu), 39-85.

[14] Rohlich, P. (1980), Tectonic Development of Al Jabal al Akhdar. In: M.J. Salem and M.T. Buserwil (Eds.), Geology of Libya, Academic Press, London., 3, 923-931. 
Porosity-Permeability Relationships in the Early Oligocene Algal Limestone Member of Wadi Al Buwayrat, Tansolukh Area, Al Jabal Al Akhdar, NE Libya

[15] Rohlich, P. (1974), Geological map of Libya, 1:250000 Al Bayda sheet, NI34-15, Explanatory Booklet, Indust. Res. Cent., Tripoli,. p 49.

[16] Abdulsamad, E.O. (1998), Paleoenvironmental distribution of Tertiary Foraminifera from carbonate facies of Northern Cyrenica (NE Libya), University of Garyounis, First Earth Sciences Conference (Abst.), 50-52.

[17] Glover P. W. J. (2011), Formation evaluation MSc course notes porosity chapter 5: Porosity, 43-53.

[18] Ehrenberg, S.N. (1990), Relationship between diagenesis and reservoir quality in sandstones of the Garn Formation, Haltenbanken, mid-Norwegian continental shelf. AAPG Bull., 74, $1538-1558$.

[19] Ehrenberg S. N., Eberli G. P. and Baechle G. (2006), Porosity-permeability relationships in Miocene carbonate platforms and slopes seaward of the Great Barrier Reef, Australia (ODP Leg 194, Marion Plateau). In: Sedimentology Journal, 53, p.1289-1318.

\section{AUTHORS' BIOGRAPHY}

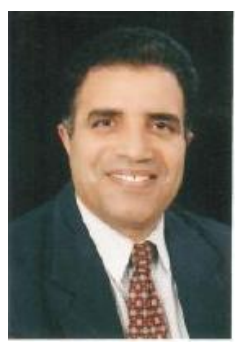

Dr. Omar B. Elfigih, is an associated professor and petroleum geologist at the Department of Earth Sciences, University of Benghazi. Head of the Department of Earth Sciences at University of Benghazi. Born in Dec.16.1959, he has an MSc. and $\mathrm{PhD}$ in petroleum geology from Memorial University of Newfoundland-Canada. Worked for the Arabian Gulf Oil Company (AGOCO) as petroleum geologist, technical advisor and led the Ghadames Basin group for hydrocarbon exploration researches. He worked as private consultant and exploration geologist with BPLibya. He is a member in many geological societies like; the Geological Association of Canada (GAC), the Earth Sciences Society of Libya (ESSL) and the American Association of Petroleum Geologists (AAPG). He published more than 25 scientific papers in peer reviewed journals and has also presented several papers in national and international meetings and seminars.

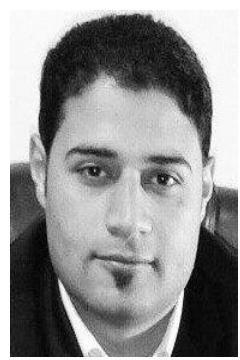

Ebrahim A. Al-Orabi, is geologist, graduated from the Earth Sciences Department, Faculty of Science at University of Benghazi. Director of studies, planning and follow-up of the General Authority for Project Management-Benghazi, Libya 